\title{
Protection of the Right to Equal Access to the Civil Service in the Context of the European Integration of Ukraine
}

\author{
There are no people purely white or very dark; \\ people are all variegated. \\ Gorky
}

The civil service and state officials in the modern world embody the state and its will. However, on the other hand, the civil service acts as an institution through which private individuals have the opportunity to participate in the implementation of public authority. The formulated conclusions derive from the provisions of Article 5 and Article 38 of the Constitution of Ukraine $^{2}$, which states that the people are the bearer of sovereignty and the only source of power in Ukraine. The people exercise power directly and through state authorities and local self-government agencies. Citizens have the right to participate in the state administration, to freely elect and be elected to state authorities and local self-government agencies.

However, it should be noted that the invoked constitutional provisions do not derive from nowhere. They owe their origin to the achievements of a large number of scholars and statesmen who at the beginning of the twentieth century researched the essence, tasks and content of the civil service, which, according to Konyk S.M. ${ }^{3}$, Voronko L.O. ${ }^{4}$,

${ }^{1}$ Tetiana Anishchenko, Candidate of law sciences, lecturer of the Postgraduate Education Centre of the State Higher Educational Institution Zaporizhzhia National University of the Ministry of Education and Science of Ukraine.

${ }^{2}$ Konstitutsiia Ukrainy, „Vidomosti Verkhovnoi Rady Ukrainy” 1996, No. 30, p. 141.

${ }^{3}$ S.M. Konyk, Derzhavna sluzhba v Ukrainckii derzhavi 1918 roku iak vitchyznianyi dosvid upravlinnia spravamy suspilstva [in:] S.M. Konyk, Publichne upravlinnia: shliakhy rozvytku: materialy naukovo-praktychnoi konferentsyi za mizhnarodnoiu uchastiu (Kyiv, 26 lystopada 2014 roku), Kyiv: NADU 2014, Vol. 2, p. 137-139.

${ }^{4}$ L.O. Voronko, Ukrainske derzhavotvorennia $v$ dobu Hetmanatu 1918 roku: rol ta znachushchist diialnosti P.Skoropadskoho, „Derzhavne upravlinnia: teoriia ta praktyka” 2016, No. 1, p. 3-20. 
V.F. Soldatenko $\mathrm{s}^{5}$ has long historical roots. Thus, it is rightly believed that the first national normative acts on the civil service came in 1918 with the active participation of P. Skoropadskyi, who attached great importance to the matters of selection, placement and training of personnel and the formation of a team of specialists and managers. The main criterion for selecting government officials was their professionalism and readiness to serve Ukraine. It was him who initiated the process of forming a civil service institution in Ukraine and the creation of government institutions (in particular the Minor Council of Ministers) necessary for the proper functioning of both the head of the state and the state mechanism as a whole ${ }^{6}$.

Further, the development of the civil service in Soviet times did take place yet was not progressive. In this period (1921-1991), there was no independent state and legal organisation in Ukraine and the state apparatus was an integral part of the party leadership ${ }^{7}$. State officials were not required to analyse political processes, dispose of resources or manage the process of implementing government decisions within the legal framework. They did not need the knowledge of economics, law, management and finances. Instead, most state officials had a technical education. Personal qualities like discipline, devotion, obedience and ability to execute orders were important ${ }^{8}$. The procedure for entering the civil service was regulated by special normative acts, and access to it was considered not a citizen's right, but a privilege'.

The starting point for the establishment of a modern domestic civil service was the adoption of the Ukrainian Civil Service Act of 16 December 1993 No. $3723-\mathrm{XII}^{10}$ which regulated social relations that covered the state's activities in creating legal, organisational, economic and social conditions for the exercise of Ukrainian citizens' right to the civil service. Particular attention in that Act was paid to ensuring the implementation of the right to the civil service by the citizens of Ukraine. In particular, this was covered in the Article 4 of the Act, which emphasised that the right to the civil service was enjoyed by the citizens of Ukraine irrespective of their origin, social and property status, race and nationality, gender, political views, reli-

${ }^{5}$ O.H. Arkusha, O.V. Boiko, Ye.I. Borodin, Istoriia derzhavnoi sluzhby v Ukraini, Holov. upr. derzh. sluzhby Ukrainy, T.V. Motrenko, V.A. Smolii, S.V. Kulchytskyi (eds.), In-t istorii NAN Ukrainy, Kijev: Nika-Tsentr, 2009, Vol. 1.

${ }^{6}$ L.O. Voronko, Ukrainske derzhavotvorennia..., p. 11-12.

${ }^{7}$ O.Yu Obolenskyi, Derzhavna sluzhba: Pidruchnyk, Kijev: KNEU 2006, p. 68.

${ }^{8}$ Istoriia derzhavnoi sluzhby na terenakh Ukrainy ta zakhody nezalezhnoi Ukrainskoi derzhavy shchodo ii stanovlennia ta rozvytku, data from the website: http://library.if.ua/book/112/7572.html (2 June 2018).

${ }^{9}$ I.P. Lavrinchuk, Pravovyi status derzhavnoho sluzhbovtsia iak uchasnyka trudovykh pravovidnosyn, Dys. kand. yuryd. nauk: 12.00.05, Kyiv 1999, p. 26.

${ }^{10}$ Pro derzhavnu sluzhbu: Zakon Ukrainy vid 16 hrudnia 1993 roku No. 3723-XII, „Vidomosti Verkhovnoi Rady Ukrainy” 1993, No. 52, p. 490. 
gious beliefs or place of residence, who had received appropriate education and training and passed the established procedure for competitive selection or through another procedure provided by the Cabinet of Ministers of Ukraine.

The cited article, in our opinion, was intended to specify the right of the citizens enshrined in the Constitution of Ukraine to be elected to state authorities or the right to equal access to the civil service, which also emphasised the inadmissibility of the existence of privileges or restrictions on grounds of race, colour, political, religious and other beliefs, gender, ethnic and social origin, property status, place of residence, language or other characteristics (Article 24(2)).

The next step towards ensuring the right to equal access to the civil service for Ukrainian citizens was the adoption of the new Civil Service Act of 10 December 2015 No. 889-VIII ${ }^{11}$, which entered into force in May 2016. The peculiarity of this Act in comparison with the previous one is, among other things, the fact that it consolidated the new principle of the civil service - ensuring equal access to the civil service ${ }^{12}$ which prohibits all forms and manifestations of discrimination, does not allow the existence of unreasonable restrictions or unjustified advantages to certain categories of citizens while applying to enter the civil service and successfully passing through.

Consequently, we can make an interim conclusion that the Constitution of Ukraine and special legislation on the civil service guarantee the citizens of Ukraine the right to equal access to the civil service. However, in order to ensure the exercise of this right, in our opinion, it is necessary to find out what the legislator understands under the notion of 'discrimination', which in the case of its manifestation in the external environment may hinder the citizens' exercise of their right to equal access to the civil service.

Passing on to the solution of the set task, we note that there are currently many definitions of the category 'discrimination'. Thus, it refers to the restriction or deprivation of the right of certain categories of citizens by race or nationality, political or religious beliefs ${ }^{13}$. The definition of 'discrimination' can also be found at the national normative level, in particular in Article 2 of the Act on the principles of prevention and combating discrimination in Ukraine" of 6 September 2012 No. 5207-VI ${ }^{14}$, where it refers

${ }^{11}$ Pro derzhavnu sluzhbu: Zakon Ukrainy vid 10 hrudnia 2015 roku No. 889VIII, „Vidomosti Verkhovnoi Rady Ukrainy” 2016, No. 4, p. 60.

${ }^{12}$ Ibidem.

${ }^{13}$ Velykyi tlumachnyi slovnyk suchasnoi ukrainskoi movy (z dod. i dopov.), V.T. Busel (eds.), Kijev, Irpin: VTF 'Perun', 2005, p. 298; V.M. Danylenko, S.A. Kokin, A.H. Sliusarenko, O.V. Danylenko, Korotkyi istorychnyi slovnyk, Zaporizhzhia: Premier 2001, p. 320.

${ }^{14}$ Pro zasady zapobihannia ta protydii dyskryminatsii v Ukraini: Zakon Ukrainy vid 6 veresnia 2012 roku, No. 5207-VI, „Vidomosti Verkhovnoi Rady Ukrainy” 2013, No. 32, p. 412. 
to the situation when a person and/or a group of persons on the grounds of race, colour, political, religious or other beliefs, gender, age, disability, ethnic or social origin, citizenship, family and property status, place of residence, linguistic or other characteristics which were, are, may be valid or presumed, is subject to restrictions on the recognition, exercise or use of the rights and freedoms in any form and established by that Act, unless in cases that such a limitation is a legitimate, objectively reasonable goal, if the methods of achievement are appropriate and necessary.

The analysis of the above definition, as well as taking into account the fact that the cited Act is instrumental in preventing discrimination in Ukraine, allows us to conclude on the possibility of extending its action to the sphere of the civil service, in particular, in terms of ensuring equal access of Ukrainian citizens to it.

The basis of international human rights law is the Universal Declaration of Human Rights ${ }^{15}$ approved by the UN General Assembly Resolution of 10 December 1948. Article 2 of the Universal Declaration of Human Rights states that „Everyone is entitled to all the rights and freedoms set forth in this Declaration, without distinction of any kind such as race, colour, sex, language, religion, political or other opinion, national or social origin, property, birth or other status. Furthermore, no distinction shall be made on the basis of the political, jurisdictional or international status of the country or territory to which a person belongs, whether it be territory is independent, trust, non-self-governing or under any other limitation of sovereignty". Pursuant to Article 7 of the Universal Declaration of Human Rights, all are equal before the law and are entitled without any discrimination to equal protection of the law. All are entitled to equal protection against any discrimination in violation of this Declaration and against any incitement to such discrimination ${ }^{16}$.

In the outlined context, one cannot but mention the Convention for the Protection of Human Rights and Fundamental Freedoms ${ }^{17}$ (signed by Ukraine on 9 November 1995 and ratified on 17 July 1997, it came into force on 11 September 1997). Article 14 of this Convention states that the enjoyment of the rights and freedoms set forth in this Convention shall be secured without discrimination on any ground such as sex, race, colour, language, religion, political or other opinion, national or social origin, association with a national minority, property, birth, or other status.

${ }^{15}$ Zahalna deklaratsyia prav liudyny [Elektronnyi resurs], data from the website: http://zakon2.rada.gov.ua/laws/show/995_015 (3 June 2018).

${ }^{16} \mathrm{H}$. Khrystova, Pytannia zaborony ta protydii dyskryminatsii. Metodychni rekomendatsii dlia yurystiv, Kyiv 2015, p. 14.

${ }^{17}$ Konventsyia pro zakhyst prav liudyny i osnovopolozhnykh svobod [Elektronnyi resurs], data from the website: http://zakon2.rada.gov.ua/laws/show/ru/995_004 (3 June 2018). 
The European Union's standards on prohibition and combating discrimination are formulated in the following documents:

- Commission Recommendation 92/131/EEC on the protection of the dignity of women and men in labour relations (27 November 1991);

- Council Declaration on the implementation of the Recommendation of the Commission on the Protection of the Dignity of Women and Men in Labor Relations, including the Code of Practice on the Suppression of Sexual Violence (19 December 1991);

- Council Directive 2000/78/ EC on the establishment of a common framework for equal treatment in employment and occupational areas (27 November 2000);

- Directive 2006/54/EC of the European Parliament and of the Council on the implementation of the principle of equal opportunities and equal treatment of men and women in matters of employment and occupation (new edition) (5 July 2006);

- Council Directive 76/207/EEC on the implementation of the principle of equal treatment for men and women in matters of employment, vocational training and career development, and working conditions (9 February 1976);

- Council Directive 2000/43/EC on the implementation of the principle of equal treatment between persons irrespective of racial or ethnic origin (29 June 2000) $)^{18}$.

The implementation of most of these Directives into national legislation is foreseen by the Action Plan of Implementing the Association Agreement between Ukraine on the one hand and the European Union, the European Atomic Energy Community and their Member States on the other hand, approved by the Decree of the Cabinet of Ministers of Ukraine of 17 September 2014 No. $847-\mathrm{p}^{19}$.

The practice of the European Court of Human Rights, which quite often outpaces the legislative process in its development, is also essential for the formation of national anti-discrimination legislation. It is more flexible and therefore more responsive to changes that take place in the state and society. Indicative in this regard are the words of the judge of the European Court of Human Rights S.V. Shevchuk, who notes that the European case law on human rights serves as an additional source of law in the application and interpretation of constitutional norms of human rights. According to the author, the recognition of the practice of the European Court of Human Rights as a source of law in Ukraine is also due to considerations of practi-

${ }^{18}$ H. Khrystova, Pytannia zaborony..., p. 24-25.

${ }^{19}$ Pro implementatsiiu Uhody pro asotsiatsiiu mizh Ukrainoiu, z odniiei storony, ta Yevropeiskym Soiuzom, Yevropeiskym Spivtovarystvom $z$ atomnoi enerhii i ikhnimy derzhavamy-chlenamy, z inshoi storony: rozporiadzhennia Kabinetu Ministriv Ukrainy vid 17 veresnia 2014 roku, No. 847-r, data from the website: http://zakon5. rada.gov.ua/laws/show/847-2014-\%D1\%80 (3 June 2018). 
cal expediency, since, according to the (Venice) Commission for Democracy through Law in terms of limited public resources, it is much better to spend funds on the necessary reforms that will help to prevent a violation of the Convention rather than to pay just satisfaction to those who already suffer from such violations ${ }^{20}$. In the context of the prevention of discrimination and the formation of national anti-discrimination legislation, the Court's rulings in Willis v. The United Kingdom ${ }^{21}$ and Okpiz v. Germany ${ }^{22}$ are very important. These cases have established that discrimination means different treatment with people in relatively similar situations, which is not the object to any reasonable or objective reasons that „are based on a feature that can be identified" 23 .

Consequently, as follows from the foregoing, a considerable number of conclusions and provisions have been formulated at national and international levels that make it possible to comprehend the essence, content and possible variants of discrimination. However, despite this, A. Oliinyk rightly notes that persons providing legal assistance to the victims often do not see discrimination where it is and are not recommended to seek protection of a relevant right on grounds of discrimination in some cases ${ }^{24}$. This, in fact, may also be explained by the absence of legal cases the object of which would be a violation of citizens' right to access the civil service on grounds of discrimination. Administrative courts mostly deal with cases of violations of the procedure for the selection of candidates for civil service positions, accrual and payment of pensions, re-employing a dismissed employee or applying a disciplinary punishment for an employee.

A 'transfer' of the definition of discrimination into the analysed sphere allows us to conclude that the equal access to the civil service for Ukrainian citizens can be provided by:

- preventing an external manifistation of any actions or processes, states or feelings aimed at restricting or depriving the citizens of this right on grounds of race, colour, political, religious or other beliefs, gender, age,

${ }^{20}$ T.S. Anishchenko, Pravo publichnoi sluzhby u systemi administratyvnoho prava Ukrainy, dysertatsiia kand. yuryd. nauk: 12.00.07, Derzh.VNZ 'Zaporiz.nats. un-t' M-va osvity i nauky Ukrainy, Zaporizhzhia, p. 65.

${ }^{21}$ Rishennia Yevropeiskoho sudu z prav liudyny „Villis proty Spoluchenoho Korolivstva”, data from the website: http://zakon2.rada.gov.ua/laws/show/980_170 (3 June 2018).

${ }^{22}$ Rishennia Yevropeiskoho sudu z prav liudyny „Okpiz proty Nimechchyny”, data from the website: http://www.srji.org/resources/search/21/ (3 June 2018).

${ }^{23}$ O. Pankevych, Zaborona dyskryminatsii: deiaki zahalnoteoretychni i filosofsko-pravovu aspekty interpretatsii (za materialamy praktyky Yevropeiskoho sudu z prav liudyny), „Visnyk Natsionalnoi akademii pravovykh nauk Ukrainy” 2014, No. 3, p. 20-31.

${ }^{24}$ Vyshchyi spetsializovanyi sud Ukrainy z rozhliadu tsyvilnykh i kryminalnykh sprav, data from the website: http://sc.gov.ua/ua/golovna_storinka/eksperti_jes_ta_ suddi_vssu_obgovorili_zakonodavchi_normi_ukrajini_cshodo_protidiji_diskriminaciji.html (3 June 2018). 
disability, ethnic or social origin, citizenship, family and property status, place of residence, linguistic or other characteristics;

- the absence of unreasonable restrictions put forward for citizens who intend to use the specified right;

- the prohibition of actions of public officials to provide unjustified benefits to certain categories of citizens while entering the civil service and successfully passing through.

Thus, summing up the considerations presented above, it should be noted that the course chosen by Ukraine to bring national legislation to European standards is undoubtedly most necessary and only possible today. Amendments to national legislation, the formation of new points of view regarding the civil service, the principles of its functioning and development are obligatory steps aimed at ensuring the equal access of citizens to the civil service.

\section{Bibliography}

Anishchenko T.S., Pravo publichnoi sluzhby u systemi administratyvnoho prava Ukrainy, dysertatsiia kand.yuryd.nauk: 12.00.07, Derzh.VNZ 'Zaporiz.nats.unt' M-va osvity i nauky Ukrainy, Zaporizhzhia.

Arkusha O.H., Boiko O.V., Borodin Ye.I., „Istoriia derzhavnoi sluzhby v Ukraini”, Holov. upr. derzh. sluzhby Ukrainy, T.V. Motrenko, V.A. Smolii, S.V. Kulchytskyi (eds.), In-t istorii NAN Ukrainy, Kijev: Nika-Tsentr 2009, Vol. 1.

Danylenko V.M., Kokin S.A., Sliusarenko A.H., Danylenko O.V., Korotkyi istorychnyi slovnyk, Zaporizhzhia: Premier 2001.

Istoriia derzhavnoi sluzhby na terenakh Ukrainy ta zakhody nezalezhnoi Ukrainskoi derzhavy shchodo ii stanovlennia ta rozvytku, data from the website: http://library.if.ua/book/112/7572.html (2 June 2018).

Khrystova H., Pytannia zaborony ta protydii dyskryminatsii. Metodychni rekomendatsii dlia yurystiv, Kyiv 2015.

Konstitutsiia Ukrainy, „Vidomosti Verkhovnoi Rady Ukrainy” 1996, No. 30.

Konventsyia pro zakhyst prav liudyny i osnovopolozhnykh svobod, dane ze strony internetowej, http://zakon2.rada.gov.ua/laws/show/ru/995_004 (3 June 2018).

Konyk S.M., Derzhavna sluzhba v Ukrainckii derzhavi 1918 roku iak vitchyznianyi dosvid upravlinnia spravamy suspilstva [in:] S.M. Konyk, Publichne upravlinnia: shliakhy rozvytku: materialy naukovo-praktychnoi konferentsyi za mizhnarodnoiu uchastiu (Kyiv, 26 lystopada 2014 roku), Kyiv: NADU 2014, Vol. 2.

Lavrinchuk I.P., Pravovyi status derzhavnoho sluzhbovtsia iak uchasnyka trudovykh pravovidnosyn, Dys. kand. yuryd. nauk: 12.00.05, Kyiv 1999.

Obolenskyi O.Yu, Derzhavna sluzhba: Pidruchnyk, Kijev: KNEU 2006.

Pankevych O., Zaborona dyskryminatsii: deiaki zahalnoteoretychni i filosofsko-pravovu aspekty interpretatsii (za materialamy praktyky Yevropeiskoho sudu z prav liudyny), „Visnyk Natsionalnoi akademii pravovykh nauk Ukrainy” 2014, No. 3.

Pro derzhavnu sluzhbu: Zakon Ukrainy vid 10 hrudnia 2015 roku, No. 889-VIII, „Vidomosti Verkhovnoi Rady Ukrainy” 2016, No. 4, p. 60. 
Pro derzhavnu sluzhbu: Zakon Ukrainy vid 16 hrudnia 1993 roku, No. 3723-XII, „Vidomosti Verkhovnoi Rady Ukrainy” 1993, No. 52.

Pro implementatsiiu Uhody pro asotsiatsiiu mizh Ukrainoiu, z odniiei storony, ta Yevropeiskym Soiuzom, Yevropeiskym Spivtovarystvom z atomnoi enerhii i ikhnimy derzhavamy-chlenamy, $z$ inshoi storony: rozporiadzhennia Kabinetu Ministriv Ukrainy vid 17 veresnia 2014 roku No. 847-r, data from the website: http://zakon5.rada.gov.ua/laws/show/847-2014-\%D1\%80 (3 June 2018).

Pro zasady zapobihannia ta protydii dyskryminatsii v Ukraini: Zakon Ukrainy vid 6 veresnia 2012 roku. No. 5207-VI, „Vidomosti Verkhovnoi Rady Ukrainy” 2013, No. 32, p. 412.

Rishennia Yevropeiskoho sudu z prav liudyny 'Okpiz proty Nimechchyny', data from the website: http://www.srji.org/resources/search/21/ (3 June 2018).

Rishennia Yevropeiskoho sudu z prav liudyny „Villis proty Spoluchenoho Korolivstva", data from the website: http://zakon2.rada.gov.ua/laws/show/980_170 (3 June 2018).

Velykyi tlumachnyi slovnyk suchasnoi ukrainskoi movy (z dod. i dopov.), V.T. Busel (ed.), Kijev: Irpin: VTF Perun 2005, p. 298

Voronko L.O., Ukrainske derzhavotvorennia v dobu Hetmanatu 1918 roku: rol ta znachushchist diialnosti P.Skoropadskoho, „Derzhavne upravlinnia: teoriia ta praktyka" 2016, No 1.

Vyshchyi spetsializovanyi sud Ukrainy z rozhliadu tsyvilnykh I kryminalnykh sprav, data from the website: http://sc.gov.ua/ua/golovna_storinka/eksperti_ jes_ta_suddi_vssu_obgovorili_zakonodavchi_normi_ukrajini_cshodo_protidiji_diskriminaciji.html (3 June 2018).

Zahalna deklaratsyia prav liudyny, data from the website: http://zakon2.rada.gov. ua/laws/show/995_015 (3 June 2018).

Abstract

The author of the article analyses the protection of the right to equal access to the civil service as one of the fundamental principles of that service itself, proclaimed both in the Constitution of Ukraine and in the Civil Service Act. The essence and content of the concept of 'discrimination' are determined, then national and international sources of law regulating the issues of discrimination researched while the features of the concept of 'equal access to the civil service' are singled out for analysis. The author studies 'protected features' as individual characteristics which should not be taken into account for the purposes of the different approach to or use of a particular good. The concept of an 'integral requirement for a profession' is considered and the limits of its application in accordance with the Ukrainian Civil Service Act are determined.

Keywords: civil service, public officials, discrimination, principles of the civil service, access to the civil service

Ochrona prawa do równego dostępu do służby cywilnej w kontekście integracji europejskiej Ukrainy

Streszczenie

Autorka analizuje ochronę prawa równego dostępu do służby cywilnej jako jedną z podstawowych zasad tej służby, zapisaną zarówno w ukraińskiej konstytucji, jak 
i w ustawie o służbie cywilnej. W artykule opisano istotę i treść idei dyskryminacji, a także poddano analizie krajowe oraz międzynarodowe źródła prawa regulujące tę kwestię i przedstawiono zasady równego dostępu do służby cywilnej. Autorka postrzega „własności chronione” jako indywidualne cechy, które nie mogą być pretekstem dla różnego podejścia do konkretnego dobra lub korzystania z niego. Rozważa koncepcję wymogów, które należy spełnić, by wykonywać dany zawód, i granice jej stosowania zgodnie z ukraińską ustawą o służbie cywilnej.

Słowa kluczowe: służba cywilna, urzędnicy państwowi, dyskryminacja, zasady służby cywilnej, dostęp do służby cywilnej 